\title{
EFFECT OF IN-VITRO ALPHA LIPOIC ACID ADDITION ON SPERMATOZOA MOTILITY IN SPERM PREPARATION PROCESS
}

\author{
Gede Wira Buanayuda, Hamdani Lunardhi, Indra Gusti Mansur \\ Department of Andrology, Faculty of Medicine, Universitas Airlangga, Dr. Soetomo Hospital, Surabaya, Indonesia
}

\section{ABSTRACT}

Infertility is a problem for husband and wife, in the last 20 years the number of infertile couples has tended to increase by around 6.5 million pairs. The infertile couple can use the intrauterine insemination method to obtain offspring if a conventional method approach cannot be performed. Insemination requires a sperm preparation stage in which there are centrifugation and resuspension procedures that tend to produce excess reactive oxygen species (ROS). Excessive ROS will damage the motility of the spermatozoa. This study aims to prove the addition of alpha lipoic acid (ALA) as an antioxidant in the process of sperm preparation to improve and maintain better sperm motility. This research is a laboratory study with an experimental research design. The sample consisted of 10 infertile men who visited the Andrology section of the Sayyidah Jakarta Mother and Child Hospital (RSIA), where each ejaculate from the patient would be divided into 3 groups namely (k1) fresh semen as a control group, (k2) sperm preparation group without ALA, $(k 3)$ group of sperm preparation with the addition of ALA. The motility of spermatozoa was observed with the WHO 1999 method for 4 hours in units of percent. Progressive motility in $k 3(47.95 \pm 3.617)$ was higher than in $k 2(38.05 \pm 3.278)$ statistically significantly different after 3 hours of observation ( $p<0.0001)$. Progressive motility in $k 3$ (78.8 \pm 5.841$)$ was higher than $k 1(56.55 \pm 7.511)$ from the initial observation $(p<0.0001)$. The progressive motility of $k 2(76.05 \pm 6.768)$ was higher than $k 1(56.55$ $\pm 7.511)$ from the start of the observation (0.0001). It can be concluded that the addition of ALA in the sperm preparation process increases and maintains progressive motility that is better than sperm preparation without ALA addition after 3 hours of observation.

Keywords: ALA; sperm preparation; motility

\section{ABSTRAK}

Infertilitas merupakan masalah bagi suami istri, dalam 20 tahun terakhir jumlah pasangan infertil cenderung meningkat sekitar 6,5 juta pasang. Pasangan infertil tersebut dapat menggunakan metode inseminasi intrauterin untuk memperoleh keturunan apabila pendekatan metode konvensional tidak dapat dilakukan. Pada inseminasi diperlukan tahapan preparasi sperma yang didalamnya terdapat prosedur sentrifugasi dan resuspensi yang cenderung menghasilkan reactive oxygen species (ROS) berlebih. ROS yang berlebih akan merusak motilitas spermatozoa. Penelitian ini bertujuan untuk membuktikan penambahan alpha lipoic acid (ALA) sebagai antioksidan pada proses preparasi sperma mampu meningkatkan dan mempertahankan motilitas sperma yang lebih baik. Penelitian ini merupakan studi laboratorium dengan rancangan penelitian eksperimental. Sampel terdiri dari 10 pria infertil yang berkunjung ke bagian Andrologi Rumah Sakit Ibu dan Anak (RSIA) Sayyidah Jakarta, dimana setiap ejakulat dari pasien tersebut akan dibagi kedalam 3 kelompok yaitu (k1) semen segar sebagai kelompok kontrol, (k2) kelompok preparasi sperma tanpa ALA, (k3) kelompok preparasi sperma dengan penambahan ALA. Motilitas spermatozoa diamati dengan metode WHO 1999 selama 4 jam dalam satuan persen. Motilitas progresif pada $k 3(47,95 \pm 3,617)$ lebih tinggi dibandingkan pada $k 2(38,05 \pm 3,278)$ secara statistik berbeda bermakna setelah 3 jam pengamatan $(p<0,0001)$. Motilitas progresif pada $k 3(78,8 \pm 5,841)$ lebih tinggi daripada $k 1(56,55$ $\pm 7,511)$ dari awal pengamatan ( $p<0,0001)$. Motilitas progresif $k 2(76,05 \pm 6,768)$ lebih tinggi dari pada $k 1(56,55 \pm 7,511)$ dari awal pengamatan (0,0001). Dapat disimpulkan bahwa penambahan ALA pada proses preparasi sperma meningkatkan dan mempertahankan motilitas progresif yang lebih baik dibandingkan preparasi sperma tanpa penambahan ALA setelah 3 jam pengamatan.

Kata kunci: ALA; preparasi sperma; motilitas

Correspondence: Gede Wira Buanayuda, Department of Andrology, Faculty of Medicine, Universitas Airlangga, Dr. Soetomo Hospital, Surabaya. Indonesia. Phone: (+62)81803740998. E-mail: buanayuda@yahoo.com

pISSN:2355-8393 • eISSN: 2599-056x • doi: http://dx.doi.org/10.20473/fmi.v55i4.17309

- Fol Med Indones. 2019;55:246-250 • Received 31 Jan $2017 \bullet$ Accepted 27 Jul 2017

- Open access under CC-BY-NC-SA license • Available at https://e-journal.unair.ac.id/FMI/ 


\section{INTRODUCTION}

Pregnancy is happy news for couples who want to have offspring. Not all couples have a good chance of obtaining offspring, many of whom experience infertility problems. In the period between 1990 and 2010 infertility rates tended to increase. At present there are many pollutants, free radicals, exposure to chemicals which make it more difficult for couples to obtain offspring by conventional means so that it requires assisted reproduction technology, one of which is intrauterine insemination (Mascarenhas et al 2012, Rutstein \& Shah 2004, Geyter et al 2010).

In the process of intrauterine insemination there is a procedure for sperm preparation in which ejaculate centrifugation and resuspension will be performed to obtain good spermatozoa. The centrifugation and resuspension process will produce ROS which adversely affects sperm motility (Agarwal et al 2005, Sikka 2004). Giving antioxidants will be useful to reduce the adverse effects of ROS (Agarwal et al 2005). As previously known, the motility of spermatozoa plays an important role in the fertilization process, among others, essential in the process of spermatozoa migration from cervical mucus, partly responsible for the process of reaching fertilization, and obligatory during egg cell penetration (Cooper \& Yeung 2010).

ALA is a potent antioxidant that can reduce the adverse effects of ROS caused by direct centrifugation and resuspension. ALA also works to help produce other antioxidants, such as glutathione (GSH) and plays a role in the energy production process, Adenosine Triphosphate (ATP). Unlike other antioxidants which only work in one of the conditions such as fat-soluble or water-soluble, intracellular or extracellular media, ALA can work equally well in both conditions, thus providing broad antioxidant activity (broad spectrum) (Islam 2009, Ibrahim 2011) . In the previous study it was found that the addition of ALA to Boer bucks cement incubated increased spermatozoa motility (Ibrahim et al 2008). In another study, a randomized triple blind placebo-controlled clinical trial found that oral administration of ALA $600 \mathrm{mg}$ for 12 weeks in infertile men significantly improved sperm motility, increased total antioxidant capacity in semen and reduced malondialdehyde (MDA) levels compared to placebo (Haghighian et al 2015), whereas in other studies that did not find a protective effect on the addition of ALA to frozen sperm motility (Hussain et al 2011). A good sperm preparation process is expected to produce good quality too, but during the process there are centrifugation and resuspension actions which actually cause high ROS. This high ROS can cause oxidative stress which decreases the motility of the spermatozoa. This certainly has its own detrimental effect so that the provision of ALA in this study is expected to improve and maintain better spermatozoa motility.

\section{MATERIALS AND METHODS}

This was a laboratory study to assess the effect of ALA on spermatozoa motility in the sperm preparation process using an experimental study design (post test only). The population of this study was infertile male patients who visited the Andrology section of the RSIA Sayyidah Jakarta. This research was conducted from September to December 2016. The sample consisted of 10 infertile men who met the inclusion and exclusion criteria. The inclusion criteria were infertile men aged 20-45 years, 3-7 days abstinence, ejaculate volume $=2$ $\mathrm{ml}$, and results of minimal or better sperm analysis from oligoasthenozoospermia with a minimum concentration of 15 million/ml WHO 1999 criteria. For exclusion criteria, among others Ejaculate $\mathrm{pH}<7.2$, leukocyte count $>1 \mathrm{million} / \mathrm{ml}$, viscosity $>2 \mathrm{~cm}$, and not willing to participate in the study.

Sampling was done by consecutive sampling according to inclusion and exclusion criteria, each ejaculate from the sample patients will be divided into 3 groups namely (k1) fresh semen as a control group, (k2) sperm preparation group without ALA, (k3) sperm preparation group with addition of ALA. The ALA preparation used was a solution for injection, where $500 \mu 1$ of cement in the $\mathrm{k} 3$ group was added with $10 \mu \mathrm{l}$ of ALA $(2.5 \mathrm{mg})$, whereas, in the $\mathrm{k} 2$ and $\mathrm{k} 1$ groups each $500 \mu \mathrm{l}$ cement was added with $10 \mu \mathrm{l}$ aqua bidestilate. Each group was incubated for 15 minutes so that additional ingredients dissolved first. In groups k2 and k3 will go through the stages of sperm preparation with the density gradient method using vitrolife medium, namely $45 \%$ medium and $90 \%$ lower medium, while for group k1 is fresh cement as a control without sperm preparation. Each group will observe its motility every hour for a period of 0-4 hours with the WHO 1999 method. The results obtained are quantitative data for the motility values of spermatozoa in units of percentages. The variables tested were spermatozoa motility with a numerical measurement scale (ratio). The types of comparative hypotheses and groups tested were 3 groups between independent samples using variance analysis (ANOVA) because the data were normally distributed and homogeneous variations. Ethical feasibility was obtained from the bioetic committee of the Faculty of Medicine, Universitas Airlangga, Surabaya.

\section{RESULTS}

Based on the Saphiro Wilk normality test, each characteristic of the research subject can be concluded that the progressive motility data (motility $a+b$ ) of 
WHO 1999 has a normal distribution $(\mathrm{p}>0.05)$ and in the levene test each characteristic of the research subject shows variations in data homogeneous ( $p>0.05)$. The following are the results of the progressive motility difference test of each group from 0-4 hour observation.

From the table above shows that the higher progressive motility values in the sperm preparation group with ALA compared to the preparation group without ALA occurred after 3 hours of observation statistically significant $(\mathrm{p}<0.0001)$, while the higher progressive motility values in the sperm preparation group with ALA compared with the control group from the start of the observation ( 0 hours) it was statistically significant ( $p<0.0001)$ and higher progressive motility values also occurred in the sperm preparation group without ALA compared to the control group from the initial observation ( 0 hours) was statistically significant $(\mathrm{p}<0.0001)$.

\section{DISCUSSION}

Oxidation stress caused by ROS is associated with disruption of the ability of spermatozoa in the fertilization process. The level of ROS increases in the process of centrifugation and resuspension carried out in the process of sperm preparation. The addition of antioxidants to the preparation media increases almost all the parameters of spermatozoa, one of which is spermatozoa motility so that it can increase the chances of success of the reproductive process assisted by protecting the spermatozoa from the oxidation stress (Chi et al 2008).

Table 1. Results of the 0-hour progressive motility difference test between groups using variance analysis

\begin{tabular}{lccc}
\hline \multicolumn{1}{c}{ Groups } & $\mathrm{N}$ & $\begin{array}{c}\text { Mean } \pm \text { Standard } \\
\text { Deviation }\end{array}$ & $\begin{array}{c}\text { p-value of } \\
\text { Anova }\end{array}$ \\
\hline Control & 10 & $56.55 \pm 7.511^{\mathrm{a}}$ & \\
preparation of sperm without ALA & 10 & $76.05 \pm 6.768^{\mathrm{b}}$ & $<0.0001$ \\
preparation of sperm with ALA & 10 & $78.8 \pm 5.841^{\mathrm{b}}$ & \\
\hline Note: Different superscripts show significant differences based on the LSD test &
\end{tabular}

Table 2. Results of 1 hour progressive motility difference test between groups using variance analysis

\begin{tabular}{lccc}
\hline \multicolumn{1}{c}{ Groups } & N & $\begin{array}{c}\text { Mean } \pm \text { Standard } \\
\text { Deviation }\end{array}$ & $\begin{array}{c}\text { p-value of } \\
\text { Anova }\end{array}$ \\
\hline Control & 10 & $47.50 \pm 4.830^{\mathrm{a}}$ & \\
preparation of sperm without ALA & 10 & $63.30 \pm 6.626^{\mathrm{b}}$ & $<0.0001$ \\
preparation of sperm with ALA & 10 & $67.10 \pm 6.050^{\mathrm{b}}$ & \\
\hline Note: Different superscripts show significant differences based on the LSD test &
\end{tabular}

Table 3. Results of the 2-hour progressive motility difference test between groups using variance analysis

\begin{tabular}{lccc}
\hline \multicolumn{1}{c}{ Groups } & N & $\begin{array}{c}\text { Mean } \pm \text { Standard } \\
\text { Deviation }\end{array}$ & $\begin{array}{c}\text { p-value of } \\
\text { Anova }\end{array}$ \\
\hline Control & 10 & $40.95 \pm 5.118^{\mathrm{a}}$ & $<0.0001$ \\
preparation of sperm without ALA & 10 & $51.45 \pm 5.909^{\mathrm{b}}$ & \\
preparation of sperm with ALA & 10 & $55.95 \pm 6.062^{\mathrm{b}}$ & \\
\hline Note: Different superscripts show significant differences based on the LSD test
\end{tabular}

Table 4. Results of the 3-hour progressive motility difference test between groups using variance analysis

\begin{tabular}{lccc}
\hline \multicolumn{1}{c}{ Groups } & N & $\begin{array}{c}\text { Mean } \pm \text { Standard } \\
\text { Deviation }\end{array}$ & $\begin{array}{c}\text { p-value of } \\
\text { Anova }\end{array}$ \\
\hline Control & 10 & $29.50 \pm 4.899^{\mathrm{a}}$ & \\
preparation of sperm without ALA & 10 & $38.05 \pm 3.278^{\mathrm{b}}$ & $<0.0001$ \\
preparation of sperm with ALA & 10 & $47.95 \pm 3.617^{\mathrm{c}}$ & \\
\hline Note: Different superscripts show significant differences based on the LSD test
\end{tabular}


Table 5. Results of 4-hour progressive motility difference test between groups using variance analysis

\begin{tabular}{lccc}
\hline \multicolumn{1}{c}{ Groups } & N & $\begin{array}{c}\text { Mean } \pm \text { Standard } \\
\text { Deviation }\end{array}$ & $\begin{array}{c}\text { p-value of } \\
\text { Anova }\end{array}$ \\
\hline Control & 10 & $18.60 \pm 2.092^{\mathrm{a}}$ & \\
preparation of sperm without ALA & 10 & $26.15 \pm 2.779^{\mathrm{b}}$ & $<0.0001$ \\
preparation of sperm with ALA & 10 & $36.25 \pm 3.093^{\mathrm{c}}$ & \\
\hline Note: Different superscripts show significant differences based on the LSD test &
\end{tabular}

This study found the addition of antioxidants in the form of ALA in the sperm preparation process resulted in a progressive motility value that was better than sperm preparation without ALA or with the control group. Damage to spermatozoa due to oxidation reaction is triggered by the imbalance of ROS levels and existing antioxidants (Sikka 2004). In the process of sperm preparation it will be eliminated by the seminal plasma in which there are antioxidants including catalase, glutathion peroxidase, superoxide dismutase, and Glutathione (GSH) so that it leaves intracellular antioxidants in sperm, namely GSH and mGSh (mitochondria), which are limited in number Increased ROS due to centrifugation and resuspension, the intracellular antioxidant content is not able to compensate for the level of ROS that appears.

The imbalance of ROS and antioxidants will trigger metabolic disorders, damage to the spermatozoa membrane so that the spermatozoa will become immotile to death. If more and more sperm are immotile and die every hour, the higher the ROS level, the more immotile and dead sperm will produce 10-15 times more ROS than motile sperm (Bourne 2009, Pyrzak 2010, Marques et al 2014, Hammadeh et al 2009). It was seen in the results of the study that progressive motility in the sperm preparation group without ALA was worse than the sperm preparation group with the addition of ALA, and it was also seen that the difference widened with increasing time.

While the difference in progressive motility that occurred in the group prepared either with or without ALA was better than the control group that was not prepared, this is more due to the sperm preparation process separating the seminal plasma in which there are seminogelin, prostaglandin, zinc, decapasitation, debris, sperm content immotil with motile spermatozoa. Factors contained in the plasma seminal can interfere with the fertilization process, with the loss of decapasitation factors, the spermatozoa will be capacitated so that hyperactivity will occur, changes in the plasma membrane and reorganization of the cytoskeleton structure at the tip of the sperm. This then causes better motility after sperm preparation (Cooper \& Yeung 2010; Fraser 1998).
In another study the administration of ALA $600 \mathrm{mg}$ for 12 weeks in infertile men significantly improved sperm motility, increased total antioxidant capacity and reduced semen malondialdehyde (MDA) (Haghighian et al 2015) and also randomized double blind placebocontrolled studies of ALA administration $600 \mathrm{mg} /$ day in infertile patients with idiopathic asthenozoospermia and oligoathenozoospermia for 3 months there was an increase in spermatozoa motility along with an increased pregnancy rate (Raaia et al 2012). So the process of intrauterine insemination requires a sperm preparation process that can control the balance of the levels of ROS and antioxidants that are present so that good motility can be produced and can last longer. When entering sperm that has been prepared into the uterus, it is most likely that the sperm does not directly fertilize the egg but will wait for the egg to be fertilized so that the ability of the spermatozoa to remain in the best quality in the uterus will increase the likelihood of pregnancy.

\section{CONCLUSION}

There is an effect that the addition of ALA in the sperm preparation process increases and maintains better spermatozoa motility after 3 hours of observation compared to sperm preparation without ALA addition and is better than the initial observation ( 0 hours) when compared to the control group that is not prepared.

\section{REFERENCES}

Agarwal A, Sushil A, Prabakaran, Said TM (2005). Prevention of oxidative stress injury to sperm. Journal of Andrology 26, 654-660

Bourne H, Archer J, Edgar D. H, Baker HWG (2009). Textbook of assisted reproductive technologies laboratory and clinical perspective. 3rd Ed; Sperm Preparation Techniques. United Kingdom, Informa Healthcare, p 53-66

Chi HJ, Kim JH, Ryu CS, Lee JY, Park JS, Chung DY, Choi SY, Kim MH, Chun EK, Roh SI (2008). Protective effect of antioxidant supplementation in sperm-preparation medium against oxidative stress in human spermatozoa. Human Reproduction; European 
Society for Human Reproduction \& Embryology 23, 1023-1028

Cooper TG, Yeung CH (2010). Andrology male reproductive health and dysfunction. 3rd Ed. Berlin, Physiology of Sperm Maturation and Fertilization. Springer, p 62-79

Fraser LR (1998). Sperm capacitation and the acrosome reaction. Human Reproduction; European Society for Human Reproduction \& Embryology 1, 9-19

Geyter CD, Geyter MD, Behre HM (2010). Andrology male reproductive health and dysfunction. 3rd Ed. Berlin, Assisted Reproduction. Springer. p 469-497

Haghighian HK, Mohammadi-asl, Dadfar M (2015). Randomized, triple-blind, placebo-controled clinical trial examining the effects of alpha-lipoic acid supplement on the spermatogram and seminal oxidative stress in infertile men. American Society for Reproductive Medicine 104, 318-324

Hammadeh ME, Fillippos AA, Hamad MF (2009). Reactive oxygen species and antioxidant in seminal plasma and their impact on male fertility. International Journal of Fertility and Sterility 3, 87-110

Hussain J, Salam A, Gohar A (2001). A study on the cryopreservation of stallion semen with alpha lipoic acid. Intl. R. J. of Pharmaceuticals 01, 21-26

Ibrahim SF, Fathihah FH, Jaffar, Osman K, Syed, Mohamed SF, Nang CF, Ismail NH, Ismail MI (2011). Bull spermatozoa motility: Optimization of coenzyme q10 and alpha-lipoic acid concentration. IIOABJ 2, 813

Ibrahim SF, Osman K, Das S, Othman AM, Majid NA, Rahman MPA (2008). A study of the antioxidant effect of alpha lipoic acids on sperm quality. Clinics $63,545-50$

Islam TM (2009). Antioxidant activities of dithiol alpha-lipoic acid. Bangladesh Journal Of Medical Science 8

Mascarenha MN, Flaxman SR, Boerma T, Vanderpoel S, Stevens GA (2012). National, regional, and global trends in infertility prevalence since 1990: A Systematic Analysis of 277 Health Surveys. PLOS Medicine 9, 1-12

Pyrzak R (2010). Manual of intrauterine insemination and ovulation induction; Semen preparation for intrauterine insemination. New York, Cambrige University Press, p 53-67

Raaia. MF, Atyeah AA, Elkhiat YI, Elenany HG (2012). Treatment of idiopathic asthenozoospermia, either isolated or oligoasthenozoospermia, with a-lipoic acid: A placebo-controlled, double-blind study. Human Andrology 2, 94-98

Rutstein SO, Shah IH (2004). Infecundity, infertility, and childlessness in developing countries. DHS Comparative Reports No. 9. Calverton, Maryland. USA, ORC Macro and the World Health Organization, p 1-41

Sikka SC (2004). Role of oxidative stress and antioxidant in andrology and assited reproductive technology. Journal of Andrology 25, 5-18

WHO (1999). Laboratory manual for the examination of human semen and sperm-cervical mucus interaction. 4th Ed. New York, WHO-Cambrige University Press 